Maurer School of Law: Indiana University

Digital Repository @ Maurer Law

1989

\title{
The Supreme Court's New Vision of Federal Habeas Corpus for State Prisoners
}

Joseph L. Hoffmann

Indiana University Maurer School of Law, hoffma@indiana.edu

Follow this and additional works at: https://www.repository.law.indiana.edu/facpub

Part of the Courts Commons, Criminal Law Commons, and the Criminal Procedure Commons

\section{Recommended Citation}

Hoffmann, Joseph L., "The Supreme Court's New Vision of Federal Habeas Corpus for State Prisoners" (1989). Articles by Maurer Faculty. 898.

https://www.repository.law.indiana.edu/facpub/898

This Article is brought to you for free and open access by the Faculty Scholarship at Digital Repository @ Maurer Law. It has been accepted for inclusion in Articles by Maurer Faculty by an authorized administrator of Digital Repository @ Maurer Law. For more information, please contactrvaughan@indiana.edu. 


\section{JOSEPH L. HOFFMANN}

\section{THE`SUPREME COURT'S NEW}

\section{VISION OF FEDERAL HABEAS \\ CORPUS FOR STATE PRISONERS}

In a 1981 law review article, Sandra Day O'Connor, then an Arizona appellate judge, suggested that our judicial system could be improved by limiting federal review of adjudications of federal constitutional questions by state courts: ${ }^{1}$

If our nation's bifurcated judicial system is to be retained, as 1 am sure it will be, it is clear that we should strive to make both the federal and the state systems strong, independent, and viable. State courts will undoubtedly continue in the future to litigate federal constitutional questions. State judges in assuming office take an oath to support the federal as well as the state constitution. State judges do in fact rise to the oceasion when given the responsibility and opportunity to do so. It is a step in the right direction to defer to the state courts and give finality to their judgments on federal constitutional questions where a full and fair adjudication has been given in the state court.

Judge O'Connor singled out federal habeas corpus review of state convictions as a notable example of our system's "strange" and "imperfect" duplication of judicial time and effort. ${ }^{2}$ Unfortunately, ac-

Joseph L. Hoffmann is Associate Professor of Law, Indiana University-Bloomington.

AurHor's Note: I thank Terry Bethel, Ellen Boshkoff, Craig Bradley, Larry Kramer, Rhonda Long-Sharp, Lauren Robel, and the participants in the Indiana University faculty workshop for their assistance.

'O'Connor, Trends in the Relationship Between the Federal and State Courts from the Perspective of a State Court Judge, 22 Wm. \& M. L. Rev. 801, 814-15 (1981).

2Id. at 801.

(C) 1990 by The University of Cbicago. All rigbts reserved.

0-226-09571-1/90/1989-0004\$02.00 
cording to Judge O'Connor, "[c]hanges and improvements come very slowly, if at all, and, more often than not, incrementally, in small case by case adjustments." 3

In 1989, as a Justice of the United States Supreme Court, Sandra Day O'Connor was able to help frustrate her own prediction about the slow pace of reform of federal habeas. Justice O'Connor's lead opinions for a plurality of the Court in Teague v. Lane, ${ }^{4}$ and for a majority in the followup case of Penry v. Lynaugh, ${ }^{5}$ significantly narrowed the scope of federal habeas by excluding claims based on "new constitutional rules of criminal procedure," or rules that are announced after a defendant's conviction becomes "final." 6 The only exceptions to the Teague rule, that "new law" does not apply retroactively to habeas cases, are decisions placing a certain defendant or conduct beyond the reach of the substantive law of crimes or pumishments, and decisions recognizing a procedural right so fundamental that, without it, the "likelihood of an accurate conviction is seriously diminished." 7

Teague generated surprisingly little reaction, perhaps because it was only a plurality decision, and perhaps because it involved the complex and seemingly "technical" issue of habeas retroactivity. Properly understood, however, and in view of its endorsement by a majority in Penry, Teague represents a watershed decision in the history of federal habeas. Put simply, Teague articulates a new vision of federal habeas that, if not overturned by the Court or by Congress, ${ }^{8}$ will eventually reshape the entire area of the law. Teague may be the most important habeas decision since Fay v. Noia. ${ }^{9}$

The impact of Teague will be felt on four different levels. First, Teague has obvious and immediate significance at the doctrinal level.

\footnotetext{
${ }^{3}$ Ibid.

${ }^{4} 109$ S. Ct. 1060 (1989). Although several parts of Justice O'Connor's Teague opinion were joined by a majority of the Court, the parts of the opinion most important to the subject of this article were joined only by Chief Justice Rehnquist and Justices Scalia and Kennedy.

s109 S.Ct. 2934 (1989).

'See Teague, 109 S.Ct. at 1075.

7 Id. at $1075-77$.

8In Teague, Justice White wrote an opinion concurring in the judgment in which he invited Congress to "correct" the Court, should it feel that the case was wrongly decided. See id. at 1079 (White, J., concurring in the judgment). At least one effort to address by legislation some of the issues raised by Teague is already under way. See Hoffmann, Retroactivity and the Great Writ: How Congress Should Respond to Teague v. Lane, 1990 B.Y.U. L. Rev. (forthcoming).

9372 U.S. 391 (1963).
} 
Although the precise meaning of terms like "new law" and "final" remains to be worked out in future cases, Teague clearly changes the rules of the habeas game, and substantially restricts the availability to federal habeas petitioners of new constitutional decisions.

Second, the doctrinal changes set forth in Teague reflect a major change at the theoretical level. Teague shifts the focus of federal habeas from the correction of constitutional errors affecting the conviction of an individual defendant to the deterrence, by means of reversing state criminal convictions, of constitutional errors by state courts. This theoretical shift is reminiscent of the Burger Court's latter-day view that the Fourth Amendment exclusionary rule is a tool for deterring police misconduct, and not an individual right of a criminal defendant. ${ }^{10}$

In addition to its doctrinal and theoretical implications, Teague will have a significant impact on habeas practice. After Teague, the lower federal courts will see more habeas petitions claiming that the state courts misapplied existing federal law, and fewer petitions asking for new constitutional rules or new interpretations of existing rules. The lower federal courts also will be much less likely to find merit in a second or subsequent habeas petition. And the Supreme Court will not review habeas cases at all, except for an occasional case in which the petition for certiorari is filed by a losing state warden, or in which an issue arises about the scope of the Teague exceptions. This is because, after Teague, alınost all certiorari petitions filed by state prisoners will be either uncertworthy, because they do not raise novel legal issues, or unreviewable, because they raise issues that cannot be decided in the petitioner's favor.

Finally, and perhaps most importantly in the long run, Teague will have an effect on the developinent of federal constitutional rules of criminal procedure. The institutional impact of Teague - the extent of which can be perceived only dimly at present-will mean that the federal courts will render fewer constitutional criminal procedure decisions and the state courts will render more. This will lead to greater variation in the way federal constitutional rules of criminal procedure are interpreted and applied in the states, and inay alter the sensitive balance between the societal interest in preventing and punishing crime and the rights of criminal defendants.

\footnotetext{
${ }^{10}$ See, e.g., Stone v. Powell, 428 U.S. 465 (1976) (holding that Fourth Amendment claims are not cognizable on federal habeas unless the petitioner was denied a "full and fair opportunity for a hearing" in the state courts); United States v. Leon, 468 U.S. 897 (1984) (holding in favor of a "good faith" exception to the Fourth Amendment exclusionary rule).
} 
I. Teague, Penry, and the Supreme Court's New Doctrine of Habeas Retroactivity

In Teague, the petitioner, a black man, appealed his state convictions on the ground that the prosecutor's use of peremptory challenges to remove black prospective jurors denied him a jury representing a fair cross-section of the community, in violation of the Sixth Amendment. The Illinois Appellate Court rejected the fair cross-section claim, ${ }^{11}$ the Illinois Supreme Court denied leave to appeal, and the Supreme Court denied certiorari. ${ }^{12}$

The petitioner then filed a petition for a writ of habeas corpus in federal district court, repeating his fair cross-section claim and adding an equal protection claim based on the prosecutor's allegedly discriminatory use of peremptory challenges. The district court denied the petition, but a panel of the Court of Appeals for the Seventh Circuit reversed, and the case was taken en banc. ${ }^{13}$ The en banc rehearing was postponed pending the Supreme Court's 1986 decision in Batson v. Kentucky, ${ }^{14}$ in which the Court held that an equal protection claim could be based on improper use of peremptory challenges in a single case. After Batson was decided, the en banc Seventh Circuit ruled that the petitioner could not benefit from the Batson equal protection holding, since Batson did not apply retroactively to habeas cases. ${ }^{15}$ The Seventh Circuit rejected the petitioner's fair crosssection claim on the merits. ${ }^{16}$

The Supreme Court granted certiorari, presumably for the purpose of deciding whether the fair cross-section requirement should apply to the petit jury, or more specifically to the use of peremptory challenges. When the decision was finally handed down, however, a majority of the Court declined to reach the merits of the fair crosssection claim. Instead, Justice O'Connor, who wrote the lead opinion in support of the Court's judgment affirming the Seventh Cir-

\footnotetext{
${ }^{11} 108$ IIl. App. 3d 891, 895-97, 439 N.E.2d 1066, 1069-71 (1982).

12464 U.S. 867 (1983).

13779 F.2d 1332 (7th Cir. 1985) (en banc).

14476 U.S. 79 (1986).

${ }^{15}$ See Allen v. Hardy, 478 U.S. 255 (1986) (per curiarn) (holding Batson does not apply retroactively to habeas cases).

16820 F.2d 832 (7th Cir. 1987) (en banc). Judge Cudahy dissented. Id. at 844.
} 
cuit, used the case to reconsider "how the question of retroactivity should be resolved for cases on collateral review." 17

The retroactivity problem posed by Teague was difficult: When a federal court reviews a habeas petition filed by a state prisoner, should it apply the law which existed at the time the prisoner was convicted, or the law which exists at the time of the habeas proceeding? Or, to put the same issue differently, when the Court's view of "the law" has changed between the time the prisoner's conviction became "final" on direct review and the time of the federal habeas proceeding, should the "new law" apply "retroactively" to the habeas case?

Before Teague, these questions were answered on a rule-by-rule basis, using the three-part balancing test set forth in the Court's 1965 decision in Linkletter v. Walker. ${ }^{18}$ The Linkletter test examined (1) the purpose of the new rule, (2) the reliance placed on the old rule, and (3) the effect on the administration of justice of retroactive application of the new rule. ${ }^{19}$ The Linkletter decision was criticized almost immediately by commentators, ${ }^{20}$ and within a few years by several members of the Court as well. ${ }^{21}$ But the Linkletter test continued to serve

\footnotetext{
17109 S.Ct. at 1069 (opinion of O'Connor, J., writing in part for the Court and in part for a plurality of the Court).

18381 U.S. 618 (1965).

${ }^{19}$ See id. at 629.

${ }^{20}$ See Beytagh, Ten Years of Non-Retroactivity: A Critique and a Proposal, 61 Va. L. Rev. 1557, 1558 \& n. 3 (1975) (citing examples); see also Haddad, The Finality Distinction in Supreme Court Retroactivity Analysis, 79 Nw. U. L. Rev. 1062 (1985). For general discussions of the retroactivity issue, see, e.g., Schaefer, The Control of "Sunbursts": Techniques of Prospective Overruling, 42 N.Y.U. L. Rev. 631 (1967); Schwartz, Retroactivity, Reliability, and Due Process: A Reply to Professor Mishkin, 33 U. Chi. L. Rev. 719 (1966); Mishkin, The Supreme Court, 1964 Term Foreword: The High Court, the Great Writ and the Due Process of Time and Law, 79 Harv. L. Rev. 56 (1965); Currier, Time and Change in Judge-Made Law: Prospective Overruling, 51 Va. L. Rev. 201 (1965); Freund, New Vistas in Constitutional Law, $112 \mathrm{U}$. Pa. L. Rev. 631 (1964); Meador, Habeas Corpus and the "Retroactivity" Illusion, 50 Va. L. Rev. 1115 (1964); Amsterdam, Search, Seizure and Section 2255: A Comment, 112 U. Pa. L. Rev. 378 (1964); Traynor, Mapp v. Ohio at Large in the Fifty States, 1962 Duke L.J. 319; Torcia \& King, The Mirage of Retroactivity and Changing Constitutional Concepts, 66 Dick. L. Rev. 269 (1962); Redlich, Constitutional Law, 1962 Survey of New York Law, 14 Syr. L. Rev. 167 (1962); Bender, The Retroactive Effect of an Overruling Constitutional Decision: Mapp v. Ohio, 110 U. Pa. L. Rev. 650 (1962); Levy, Realist Jurisprudence and Prospective Overruling, 109 U. Pa. L. Rev. 1.(1960).

${ }^{21}$ See, e.g., Desist v. United States, 394 U.S. 244, 256 (1969) (Harlan, J., dissenting) (criticizing Linkletter approach on grounds of inconsistency with judicial role); Mackey v. United States, 401 U.S. 667, 675 (1971) (Harlan, J., dissenting and concurring in the judginent) (same); id., at 713 (Douglas, J., joined by Black, J., dissenting) (criticizing Linkletter approach on grounds that all new rules should apply retroactively in habeas cases).
} 
as the benchmark for habeas retroactivity, until the Court decided to reexamine the issue in Teague.

Although Justice O'Connor's lead opinion in Teague, which was joined in full by three Justices and in part by two others, addressed several issues, for present purposes I shall discuss only four portions of the opinion, each of which was joined by a four-member plurality of the Court that included Chief Justice Rehnquist and Justices Scalia and Kennedy. For clarity's sake, I will also rearrange the order of the discussion.

In the most important portion of her opinion, Justice O'Connor declared that "new constitutional rules of criminal procedure will not be applicable to those cases which have become final before the new rules are announced." 22 She identified several reasons for adopting a general rule of non-retroactivity on habeas, including the inconsistent and confusing results often produced by the Linkletter test and the fact that the Linkletter test occasionally led to the disparate treatment of similarly situated habeas petitioners. The most important reason for the new habeas retroactivity rule, however, was Justice O'Connor's contention that the purpose of federal habeas is to deter state courts from ignoring or erroneously construing federal constitutional standards. According to Justice O'Connor, "[i]n order to perform this deterrence function, the habeas court need only apply the constitutional standards that prevailed at the tine the original proceedings took place."23 Justices Stevens and Blackmun, although they did not join this portion of Justice O'Connor's opinion, agreed with her view that "new law" generally should not apply retroactively to habeas cases. ${ }^{24}$

In another significant portion of her opinion, Justice O'Connor discussed the meaning of the term, "new law," for purposes of applying the Teague retroactivity rule. She admitted that deciding whether a case announces a "new rule" is difficult, but concluded that, in general, "a case announces a new rule when it breaks new ground or imposes a new obligation on the States or the Federal Government."25 As examples of "new law," she cited the Court's decisions in Rock $v$.

22109 S.Ct. at 1075 (opinion of O'Connor, J.).

${ }^{23}$ See Desist, 394 U.S. at 262-63 (Harlan, J., dissenting).

${ }^{24} 109$ S.Ct. at 1080 (Stevens, J., joined by Blackmnn, J., concurring in part and concurring in the judgment).

${ }^{25}$ Id. at 1070. 
Arkansas, ${ }^{26}$ holding that per se exclusion of hypnotically refreshed testimony violates a defendant's right to testify on his own behalf, and Ford $v$. Wainwrigbt, ${ }^{27}$ holding that the Eighth Amendment prohibits the execution of insane persons. In sum, "a case announces a new rule if the result was not dictated by precedent existing at the time the defendant's conviction became final."28

Next, Justice O'Connor identified two exceptions to the Teague retroactivity rule. The first exception allows for retroactive application of new rules that place "certain kinds of primary, private individual conduct beyond the power of the criminal law-making authority to proscribe." 29 The second exception permits retroactive application of new rules "without which the likelihood of an accurate conviction is seriously diminished, ${ }^{30}$ such as rules barring the domination of trials by mob violence, a prosecutor's knowing use of perjured testimony, and the use of confessions coerced by "brutal methods."

Finally, Justice O'Connor stated that retroactivity is a threshold question that should be resolved prior to a decision on the merits. According to Justice O'Connor, if a habeas court were to declare a new constitutional rule of criminal procedure, without applying it on behalf of the petitioner, the court would be issuing an advisory opinion. But if the court were to announce a new rule and apply it on behalf of the petitioner, then the principle of equal treatment would require that all other habeas petitioners also benefit from the new rule, eliminating any possibility of non-retroactivity. The better view, therefore, is that the habeas court must resolve the retroactivity issue first, deciding the merits of the petitioner's claim only if the new rule sought is one that would apply retroactively to habeas cases.

Applying these principles to Teague's fair cross-section claim, Justice O'Connor, writing for the same four-member plurality, concluded that the claim was based on "new law," that it was governed by the Teague retroactivity doctrine, and that it did not fit within either of the exceptions that would have warranted retroactive applica-

\footnotetext{
26483 U.S. 44 (1987).

27477 U.S. 399 (1986).

28109 S.Ct. at 1070 .

${ }^{29}$ See Mackey, 401 U.S. at 692 (Harlan, J., dissenting and concurring in the judgment).

${ }^{30}$ Teague, 109 S.Ct. at 1077.
} 
tion. Accordingly, because Teague would not be entitled to relief even if his interpretation of the law were to prevail, the Seventh Circuit properly denied Teague's habeas petition. Justices White, Stevens, and Blackmun concurred in the judgment, although Justices Stevens and Blackmun disagreed with Justice O'Connor on the scope of the second Teague exception and on the threshold nature of the retroactivity issue. Justices Brennan and Marshall dissented.

In Penry v. Lynaugh, ${ }^{31}$ a case decided four months after Teague, Justice O'Connor was able to clarify some of the language in Teague and obtain a fifth vote for some of the views she expressed there. Penry involved a mentally retarded Texas man who had been convicted of capital murder and sentenced to death. On appeal, the Texas courts rejected Penry's claims that the jury was inadequately instructed at the sentencing phase of the trial, that the Texas death penalty system improperly limits the jury's consideration of mitigating circumstances, and that the imposition of the death penalty against mentally retarded persons violates the Eighth Amendment. ${ }^{32}$ The Supreme Court denied certiorari. ${ }^{33}$

Penry then filed a habeas petition in federal district court, alleging that the Eighth Amendment requires jury instructions on mitigating circumstances in capital sentencing, and that the use of the death penalty against mentally retarded persons violates the Eighth Amendment. The district court demied relief, and the Court of Appeals for the Fifth Circuit affirmed. ${ }^{34}$ The court stressed, however, that it did not believe the jury that sentenced Penry to death could have given full effect to the nuitigating evidence of Penry's mental retardation, in light of the Texas death penalty system and the jury instructions at sentencing. On the jury instruction claim, the court based its affirmance on Circuit precedent.

On certiorari, the Suprene Court first had to decide whether the Teague retroactivity doctrine applies to capital sentencing. In a portion of her lead opinion that was joined by a majority of the Court including Chief Justice Rehnquist and Justices White, Scalia, and Kennedy, Justice O'Connor explained that finality concerns are as relevant to capital sentencing as they are to convictions. She con-

\footnotetext{
${ }^{31}$ Note 5 supra.

32Penry v. State, 691 S.W.2d 636 (Tex. Crim. App. 1985).

${ }^{33}$ Penry v. Texas, 474 U.S. 1073 (1986).

${ }^{34}$ Penry v. Lynaugh, 832 F.2d 915 (5th Cir. 1987).
} 
cluded that the Teague rule, along with its two exceptions and the requirement that retroactivity be treated as a threshold issue, applies to new constitutional rules in the context of capital sentencing. ${ }^{35}$

Having held that Teague applies to capital sentencing, the Court faced two retroactivity issues. Penry's jury instruction claim was based on Lockett v. Obio ${ }^{36}$ and Eddings $v$. Oklaboma, ${ }^{37}$ both decided well before Penry's trial, in which the Supreme Court ruled that a defendant has an Eighth Amendment right to present any and all mitigating evidence that might cause a sentencer to returu a life verdict. But the Court had also upheld the facial validity of the Texas death penalty system in several cases, noting that the Texas system seems to allow full consideration of mitigating circumstances by the sentencing jury despite the absence of any reference to such circumstances in the jury instructions. ${ }^{38}$ Thus, the first question was whether Penry's jury instruction claim would require the Court to make "new law" in his behalf.

Justice O'Connor, writing for a majority including Justices Brennan, Marshall, Blackmun, and Stevens, reiterated her Teague definition that a "new rule" is one that is not "dictated by precedent existing at the time the defendant's conviction became final." 39 The Court's decisions upholding the Texas death penalty system, most of which predated Penry's conviction, had emphasized that the Eighth Amendment requires full consideration of mitigating circumstances by a capital sentencing jury. These decisions, along with Lockett and Eddings, effectively "dictated" that Texas sentencing juries must, upon a defendant's request, be given instructions that permit full consideration of mitigating circumstances. Moreover, the Court's decisions upholding the Texas death penalty system were premised on assurances that the system allowed full consideration of mitigating

\footnotetext{
${ }^{35}$ The same portion of Justice O'Connor's opinion also reiterated her Teague view that retroactivity should be treated as a threshold issue, and that a habeas court should address the merits of a petitioner's "new law" claim only if it finds that the "new law" would apply retroactively on habeas. Justices Brennan, Marshall, Blackmum, and Stevens declined to join this portion of Justice O'Connor's opinion. However, Justices Brennan and Marshall joined another portion of Justice O'Connor's opinion in which she made the same point about the threshold nature of the habeas retroactivity issue. It is not clear whether the decision to join Justice O'Connor on the threshold point was intentional or a mistake on the part of Justices Brennan and Marshall.

36438 U.S. 586 (1978).

37455 U.S. 104 (1982).

${ }^{38}$ See, e.g., Lowenfeld v. Phelps, 484 U.S. 231 (1988); Adams v. Texas, 448 U.S. 38 (1980); Jurek v. Texas, 428 U.S. 262 (1976).

${ }^{39} 109$ S.Ct. at 2944.
} 
circumstances. Penry's jury instruction claim thus did not seek to "impos[e] a new obligation" on the State of Texas. Instead, Penry's claim was simply that "those assurances [made by the state in prior cases] were not fulfilled in bis particular case, ${ }^{\text {"40 }}$ given the unique nature of his mitigating evidence and the language of the jury instructions. In short, the claim was not based on a "new rule," and the Court could consider it on its merits.

The second habeas retroactivity issue in Penry dealt with the scope of the Teague exceptions. Penry's claim that the Eighth Amendment bars the use of the death penalty against mentally retarded persons obviously would require the Court to adopt a "new rule." Thus, in the absence of an exception, the Court would be unable to consider the claim on its merits, since the "new rule" would not apply retroactively to Penry's case.

Justice O'Connor, writing for Justices Brennan, Marshall, Blackmun, and Stevens, focused on the exception for "new rules" that place "certain kinds of primary, private individual conduct beyond the power of the criminal law-making authority to proscribe." 41 The purpose of this exception, according to Justice O'Connor, is to allow retroactive application of new rules based on "substantive categorical guarantees" contained in the Constitution. The Court had previously found such guarantees in the Eighth Amendment, at least with respect to punishments, as well as in the Due Process Clause. Thus, Justice O'Connor held, the exception should include "not only rules forbidding criminal punishment of certain primary conduct but also rules prohibiting a certain category of punishment for a class of defendants because of their status or offense." 42 As a result, the Court again could consider Penry's claim on its merits.

A majority of the Court ultimately rejected Penry's claim that the Eighth Amendment bars the death penalty for mentally retarded persons, although Justice O'Connor split with Chief Justice Rehnquist and Justices White, Scalia, and Kennedy on the reasons for this rejection. A different majority of the Court reversed Penry's death sentence, however, and ordered a new sentencing hearing based on the jury instruction claim, with Justices Brennan, Marshall, Blackmun, and Stevens joining the portion of Justice O'Connor's opinion announcing and explaining the reversal. Justice Scalia, joined by the

\footnotetext{
40Id. at 2947.

${ }^{41}$ See Mackey, 401 U.S. at 692 (Harlan, J., dissenting and concurring in the judgment).

42109 S.Ct. at 2953.
} 
Chief Justice and Justices White and Kennedy, dissented on the ground that the jury instruction claim was based on "new law" and therefore should not have been heard on the merits under Teague.

\section{Teague and the Court's New Theory of Federal Habeas}

The doctrinal changes set forth in Teague and Penry are closely linked to the Court's view about the underlying theory of federal habeas. Because the Court in Teague lacked meaningful historical guidance on the issue of habeas retroactivity, it was compelled to resolve the issue by reference to theoretical considerations. The doctrine announced in Teague, and adopted by a majority of the Court in Penry, was the product of a theory of habeas which was first articulated by Justice Harlan in the late $1960 \mathrm{~s},{ }^{43}$ but which before last Term had never been adopted by the Court. The theory, which holds that the purpose of habeas is to deter the state courts from committing constitutional errors, emerged in Teague and Penry as an attractive choice for those Justices who, like Justice O'Connor, were concerned about the proper allocation of responsibility between the state and federal courts in the area of constitutional criminal procedure.

\section{A. THE LACK OF HISTORICAL GUIDANCE ON THE HABEAS RETROACTIVITY ISSUE}

Habeas retroactivity was not addressed by the Supreme Court before Linkletter $v$. Walker because, as a practical inatter, the issue almost never arose. ${ }^{44}$ Until the mid-20th century, the Court narrowly

\footnotetext{
${ }^{43}$ See Desist v. United States, 394 U.S. 244, 256 (1969) (Harlan, J., dissenting); see also Mackey, 410 U.S. at 675 (Harlan, J., dissenting and concurring in the judgment).

${ }^{44}$ In a footnote to the nuajority opinion in Linkletter, 381 U.S., at 628-29 n. 13, Justice Clark cited several exainples of pre-Linkletter cases in which the Court applied "new law" to habeas cases without discussing the issue of retroactivity: "Eskridge v. Wasbington Prison Board, 357 U.S. 214 (1958), applied the rule of Griffin v. Illinois, 351 U.S. 12 (1956), requiring the State to furnish trauscripts of the trial to indigents on appeal, to a 1935 conviction. The rule in Gideon $\mathrm{v}$. Wainwright, 372 U.S. 335 (1963), that counsel must be appointed to represent an indigent charged with a felony, was actually applied retrospectively in that case since Gideon had collaterally attacked the prior judgment by post-conviction reniedies. See also Dougbty v. Maxwell, 376 U.S. 202 (1964). Jackson v. Denno, 378 U.S. 368 (1964), involving a coerced confession, was also applied to the petitioner who was here on a collateral attack. See also McNerlin v. Denno, 378 U.S. 575 (1964). It is also contended that Reck v. Pate, 367 U.S. 433 (1961), supports the conclusion of absolute retroactivity in the constitutional area since the petitioner convicted in 1937 was relcased after a finding that the confession was coerced when judged by standards set forth in our cases decided subsequent to his conviction. See United States ex rel. Angelet v. Fay, 333 F.2d 12, 24 (dissenting opinion of Marshall, J.)."
} 
limited the Act of 1867 , which first authorized federal habeas review of state criminal convictions, to challenges to the jurisdiction of the state court. ${ }^{45}$ Even where the Court stretched the concept of jurisdiction to consider claims of constitutional error, it would not hear such claims on the merits if the state court had provided the defendant a "fair opportunity" to litigate the claims. ${ }^{46}$ Federal habeas, in short, was rarely available to state prisoners. And, of course, until the 1960s and the rise of the incorporation doctrine, the Court simply did not have much constitutional law to apply to state criminal proceedings.

In Brown v. Allen, ${ }^{47}$ in 1953, the Court expanded the availability of the statutory writ, for the first time reaching the merits of a petitioner's constitutional claim without even attempting to link those claims to the jurisdiction of the state court. Nevertheless, even after Brown, the habeas retroactivity issue did not arise often, because habeas petitioners were still required to have raised their constitutional claims properly in state court in order to obtain later habeas relief. 48

Habeas retroactivity first became important in 1963, when the Court issued its landmark decision in Fay v. Noia. ${ }^{49}$ In Fay, the Court, per Justice Brennan, held that in some cases habeas relief could be granted even though the petitioner had failed to raise his constitutional claim in the state courts. After Fay, prisoners were free to file habeas petitions based on "new law" that did not exist at the time of their trials. And, at the same time, the Court's move toward incorporation of the Bill of Rights spurred the development of new constitutional rules of criminal procedure. This combination of the expansion of the scope of federal habeas and the changes in federal constitutional rules of criminal procedure triggered the first wave of habeas retroactivity cases, including Linkletter.

Habeas retroactivity, in other words, is an issue that is less than

${ }^{45}$ See Friedman, A Tale of Two Habeas, 73 Minn. L. Rev. 247, 262-63 (1988); Mayers, The Habeas Corpus Act of 1867: The Supreme Court as Legal Historian, 33 U. Chi. L. Rev. 31, 54 n. 89 (1965).

${ }^{46}$ See Bator, Finality in Criminal Law and Federal Habeas Corpus for State Prisoners, 76 Harv. L. Rev. 441, 462 (1963).

47344 U.S. 443 (1953).

${ }^{48}$ As Justice Harlan pointed out in Desist, "[i]t was the rare case in which the habeas petitioner had raised a 'new' constitutional argument both at his original trial and on appeal." 394 U.S. 244, 261 (1969) (Harlan, J., dissenting).

49372 U.S. 391 (1963). 
thirty years old. Moreover, although Linkletter was a case of statutory construction, and although stare decisis is normally at its strongest in such cases, Linkletter was an unusual case of statutory construction. The post-Civil War history of federal habeas reveals that Congress either has followed the lead of the Supreme Court in defiming the scope of federal habeas, or has remained completely silent in the face of the Court's numerous decisions interpreting the Act of 1867 . As a result, the Court has come to view the construction of the Act of 1867 as a subject almost completely within its own domain. ${ }^{50}$

Nor has Congress chosen to address habeas retroactivity during the quarter-century since the Court first dealt with the issue in Linkletter. The only hint of Congressional intent on the subject is contained in a 1966 amendment to 28 U.S.C. Section 2244 (c), which deals with the res judicata effect of a decision in a habeas case on a later case filed by the same petitioner. The circumstances identified by Congress that would warrant relief on a new federal habeas petition filed by the same petitioner, where the Supreme Court had affirmed the denial of the previous petition, include "the existence of a material and controlling fact which did not appear in the record of the proceeding in the Supreme Court." ${ }^{51}$ Congress did not mention, as a legitinuate reason for filing a new petition, a change in the goverming law. And it seems unlikely that Congress would have limited new petitions in this way, if it believed that clainus based on changes in the goverming law should be cognizable in a petitioner's first habeas petition. In any event, however, this simgle, indirect treatment of the retroactivity issue does not permit the conclusion that Congress has established a policy on the issue.

\section{B. THE COMPETING THEORIES OF FEDERAL HABEAS}

Not surprisingly, given this lack of historical guidance, the debate about habeas retroactivity in Teague was transformed into a debate about the theory of federal habeas. Justice O'Connor, for the plurality, argued that a general rule of non-retroactivity, and not the Linkletter balancing test, was consistent with the theory that the purpose of federal habeas is to provide an incentive for state judges "to

\footnotetext{
${ }^{50}$ In Wainwright v. Sykes, for example, the Court referred to its "historic willingness to overturn or modify its earlier views of the scope of the writ, even where the statutory language authorizing judicial action has remained unchanged." 433 U.S. 72,81 (1977).

5128 U.S.C. $\$ 2244$ (c) (1964 ed., Supp. V) (emphasis added).
} 
conduct their proceedings in a manner consistent with established constitutional principles." 52 If state judges fail to do so, then the federal courts will grant writs of habeas corpus, overturning convictions and releasing prisoners from state custody. Presumably state judges do not wish to see their judgments upset in the federal courts, and do not wish to see persons convicted in their courtrooms set free. Federal habeas thus operates as a deterrent, ensuring that state judges will "toe the constitutional mark." 53

Justice Brennan, in his Teague dissent, relied upon the competing theory of federal habeas that he had articulated with great force and conviction in his opimon for the Court in Fay v. Noia. ${ }^{54}$ There, Justice Brennan wrote that the common-law history of the writ shows that "its function has been to provide a prompt and efficacious remedy for whatever society deems to be intolerable restraints." 55 Federal habeas ensures that imprisonment "conform[s] with the fundamental requirements of law," and provides "a mode for the redress of denials of due process of law."56 About the Act of 1867, Justice Brennan wrote that Congress "was anticipating resistance to its Reconstruction measures," and made federal habeas available to prisoners in state custody so that "federal constitutional rights of personal liberty shall not be denied without the fullest opportunity for plenary federal review." 57 In short, according to Justice Brennan, federal habeas is available "whenever a person's liberty is unconstitutionally restrained." 58

Which of these two competing theories of federal habeas articulated in Teague, the "deterrence of state courts" theory or the "vindication of federal rights/protection of liberty" theory, is correct as a matter of legislative intent? In the overwhelming majority of federal habeas cases, the answer is "both." In the typical habeas case, the federal rights of the defendant are violated by an error committed by the state court, and a grant of habeas relief thus serves both purposes:

52109 S.Ct. at 1073, quoting Desist v. United States, 394 U.S. 244, 262-63 (1969) (Harlan, J., dissenting).

${ }^{53}$ Mackey v. United States, 401 U.S. 667, 687 (1971)(Harlan, J., dissenting and concurring in the judgment).

s4Note 9 supra.

ss 372 U.S. at $401-2$.

56 Id. at 402 .

${ }^{57} I d$. at $415,424$.

${ }^{58}$ Teague, 109 S.Ct. at 1084 (Brennan, J., dissenting). 
It vindicates the petitioner's federal rights, and by doing so it serves to deter the state courts from ignoring or misconstruing such rights in the future.

Nor could the Congress that adopted the Act of 1867 have distinguished between the purpose of protecting the federal rights of defendants and the purpose of deterring state court misconduct. As Justice Brennan noted in Fay, the Act of 1867 was adopted in an effort to ensure that state courts would faithfully enforce Reconstructionera legislation, primarily those laws providing federal rights to freed slaves. This interpretation of the legislative intent, on the surface, seems consistent with the theory that the purpose of habeas is to deter state courts from ignoring or misapplying federal law. Of course, the Reconstruction Congress would also have willingly agreed that the purpose of the Act of 1867 was to protect the persons in whose behalf those federal laws had been, or were about to be, enacted. From the point of view of the Congress in 1867, the two theories of federal habeas would have been functionally equivalent.

Only with the Court's expansion of the scope of federal habeas in Brown and Fay did the "deterrence of state courts" and "vindication of federal rights/protection of liberty" theories of federal habeas become at least potentially separable. As soon as prisoners were permitted to raise claims of error based on the adoption of new constitutional rules, then it began to matter which of the two theories of federal habeas prevails. The "new law" cases raised, for the first time, the issue whether habeas relief should be granted solely for the purpose of vindicating current interpretations of federal law, even though the state courts had decided the case properly under the federal law as it existed at the time and therefore did not need or deserve to be sent a deterrence "message."

Cases such as Teague and Penry represent a crucial theoretical fork in the habeas road. They are the only class of habeas cases in which a defendant's federal constitutional rights, as understood at the time of the habeas proceeding, might have been violated, even though the state court conducted the defendant's trial in compliance with all then-applicable federal constitutional standards.

Interestingly, there is another class of habeas cases that presents a "mirror image" of the Teague retroactivity problem. That is the class of cases like Stone v. Powell, ${ }^{59}$ in which the Court held that Fourth

59428 U.S. 465 (1976). 
Amendment claims are not cognizable on federal habeas. The Stone Court wrote that the Fourth Amendment exclusionary rule is not a personal right of the defendant, but instead exists solely as a tool to deter police misconduct. Under Stone, when a state court violates existing Fourth Amendment law, the court may need a deterrence "message," 60 but the defendant has no personal right that needs to be vindicated. Once one treats the Fourth Amendment exclusionary rule as a prophylactic device, then the Fourth Amendment context, like the Teague "new law" context, is one in which the two purposes of habeas can be separated. ${ }^{61}$

\section{THE DEFINITION OF "NEW LAW"}

The Court's adoption of the "deterrence of state courts" theory of federal habeas, in Teague and Penry, has important doctrinal consequences. For example, because the theory holds that the purpose of habeas is to provide an incentive for state judges to do what the Court believes they are supposed to do, the definition of "new law," which determines the scope of federal judicial oversight of a state judge's decision, becomes the crucial element of the Teague rule. Beneath this definition lurks the following question: What is the appropriate standard of care for state judges deciding federal constitutional issues? Or, more to the point, what is the standard of care to which state judges should be held by their federal counterparts?

These are, to say the least, questions without easy answers. One approach, suggested by Justice Scalia in his Penry opinion, is that a state judge should be expected to do no more than act "reasonably" and "in good faith." 62 This "reasonable good faith" standard of care would shield most kinds of constitutional error in state criminal trials from federal habeas review. In a case where a state judge is faced with "palpable uncertainty as to what the [Supreme Court's] rule might

\footnotetext{
${ }^{60}$ See Bradley, Are the State Courts Enforcing the Fourth Amendment? A Preliminary Study, 77 Geo. L.J. 251 (1988).

6IThe Stone Court held, in effect, that a grant of habeas relief to fulfill the "deterrence of state courts" purpose, if such a grant of relief would not also serve the "vindication of federal rights/protection of liberty" purpose, is inappropriate. This, of course, does not compel the conclusion that a grant of habeas relief to fulfill the "vindication of federal rights/protection of liberty" purpose, if it would not also serve the "deterrence of state courts" purpose, is liketwise inappropriate.

62109 S.Ct. at 2964 (Scalia, J., concurring in part and dissenting in part).
} 
be,"63 for example, any careful, good faith attempt to decipher the meaning of the Supreme Court's precedents would insulate the state judge's ruling from reversal by a federal habeas court. Even a later decision by the Supreme Court replacing such "palpable uncertainty" with a clearer rule would not trigger habeas review of the conviction.

The only kind of case that can be reversed on federal habeas, under Justice Scalia's "reasonable good faith" standard, is one in which the state judge misapplies clear, binding federal precedent. Justice Scalia's view is therefore analogous to the minimal duty imposed on a police officer in a search warrant case under the current construction of the Fourth Amendnient exclusionary rule.

At the opposite extreme is the functional equivalent of "strict liability," under which a state judge is subject to reversal by a federal habeas court any time the judge gets a federal issue wrong, regardless of how reasonable the judge's conclusion may have seemed at the time. This is, in effect, a doctrine of full habeas retroactivity. The few judges and commentators who have held this view, such as Justice Douglas, are not concerned about "deterring" state judges at all. ${ }^{64}$ As is true of strict liability in other contexts, such as tort law and criminal law, strict liability in the habeas context provides no greater deterrence than a rule requiring a minimal degree of fault or culpability on the part of the actor involved. ${ }^{65}$ Rather, the "strict liability" approach is concerned with providing a remedy for the injured party, or in this context, the defendant whose conviction was tainted by constitutional error.

In Teague, and agam in Penry, Justice O'Connor unfortunately treats the "new law" issue as if it could be resolved simply by consulting an appropriate legal dictionary. "New law," to repeat the words of Justice O'Connor in Teague, is the end result of any case that "breaks new ground or imposes a new obligation on the States or the Federal Government," 66 or in which "the result was not dictated by precedent existing at the time the defendant's conviction became final." 67

\footnotetext{
${ }^{63} \mathrm{Ibid}$.

GSee Mackey, 401 U.S. at 713 (Douglas, J., joined by Black, J., dissenting).

${ }^{65}$ See Packer, Mens Rea and the Supreme Court, 1962 Supreme Court Review 107, 109.

${ }^{66} 109$ S.Ct. at 1070.

67lbid.
} 
Based on her application of the "new law" standard in Teague and Penry, Justice O'Connor's view of "new law" appears to lie somewhere between "reasonable good faith" and "strict liability." Nevertheless, there is reason for concernabout where Justice $\mathrm{O}^{\prime} \mathrm{Connor}$, as the swing vote, stands on this issue. According to Justice O'Connor, state judges should not have been expected to anticipate the Supreme Court's decisions in Rock v. Arkansas ${ }^{68}$ and Ford v. Wainwright, ${ }^{69}$ the two examples of "new law" cited in Teague. Her citations to Rock and Ford are most curious. Rock involved a relatively minor extension of longstanding federal constitutional precedent to a narrow factual situation. And Ford was a case in which several centuries of common law, as well as the statutes of virtually every state, already recognized the right at issue. The only question in Ford was whether the Court would find the right within the Eighth Amendment as well.

The citations to Rock and Ford suggest that, in Justice O'Connor's view, state judges need not be expected to do any more than fill in the most obvious interstitial gaps in the existing federal precedents in order to avoid reversal on habeas. This represents, however, an inappropriately crabbed view of the duties of a state judge when interpreting federal constitutional law. As Justice Fortas wrote in a dissent to an early habeas retroactivity decision, "it is proper for a habeas court to require 'conceptual faithfulness' to our opinions and 'not merely decisional obedience' to the rules they announce."

Justice O'Connor's definition of "new law" in Teague is much broader, and thus less favorable for defendants, than the standard previously used to decide whether a retroactivity issue exists. Before Teague, a new rule was considered "new law" only if it represented a "clear break with the past," 71 or if it "overrule[d] clear past precedent, or disrupt[ed] a practice long accepted and widely relied upon. "72 Given the tendency of all courts to characterize new rules as mere incremental changes in the law, the "clear break" standard was not often met. After Teague, however, almost all new rules will qual-

68483 U.S. 44 (1987).

69477 U.S. 399 (1986).

${ }^{70}$ Desist v. United States, 394 U.S. 244, 277 (1969) (Fortas, J., dissenting).

${ }^{71} I d$. at 248.

${ }^{72}$ Milton v. Wainwright, 407 U.S. 371, 381 n.2 (1972) (Stewart, J., dissenting). 
ify as "new law," since it will be difficult to say that such rules are "dictated by prior precedent."73

It is ironic that the Court's definition of "new law," as expressed by Justice O'Connor in Teague, places so little responsibility on a state judge to anticipate changes in the governing federal law. The standard of care for state judges under Teague is substantially less burdensome than that applicable to a defendant and his attorney under the Court's procedural default doctrine of Wainwright v. Sykes. ${ }^{74}$ The Court expects a defense attoruey, or even a pro se defendant, to raise at trial any legal challenges that have been made to courts in other cases, or that have been accepted by another court anywhere in the country. If the attoruey or defendant fails to raise such an issue at trial, in violation of a state procedural rule, then the issue is generally unavailable as a basis for later habeas relief.

The Teague doctrine does not change the way in which the procedural default rule works against habeas petitioners. But Teague does effectively overrule the Court's decision in favor of the petitioner in Reed $v$. Ross, ${ }^{75}$ where the petitioner was allowed to raise a procedurally defaulted claim on federal habeas because the claim was sufficiently "novel" at the time of the petitioner's trial that his attorney could not be faulted for failing to raise it. After Teague, any claim as "novel" as the one in Reed v. Ross will not apply retroactively to habeas cases anyway, so procedural default becomes irrelevant.

Of course, the role of a state judge differs from that of a defense attorney or defendant. We do not want a judge to decide a case in a defendant's favor based on the mere fact that the same issue was raised in another case or accepted by another judge. Instead, we want state judges to decide cases based on their best judgment about what the applicable law is, and how that law applies to the case at bar.

\footnotetext{
${ }^{73}$ In Teague, Justice Brennan supported this conclusion by citing nineteen recent Supreme Court habeas eases in which the requested new rule would have been "new law" under Justice O'Connor's definition. 109 S.Ct. at 1088-1090 (Brennan, J., dissenting). Many of the 19 cases did not give rise to retroactivity issues under the pre-Teague "new law" standard. The "new law" definition in Teague retains some flexibility, as evidenced by the lengthy discussion of the "new law" issue in Penry. See 109 S.Ct. at 2944-47 (opinion of O'Connor, J.); id. at 2964-65 (Scalia, J., concurring in part and dissenting in part). This flexibility would permit a future Court to narrow the definition without explicitly overruling it. Nevertheless, the Teague definition clcarly increases the likelihood that a new rule will be held to be "new law" for retroactivity purposes.
}

74433 U.S. 72 (1977).

75468 U.S. 1 (1984). 
There is something unseemly, however, about adopting a definition of "new law" for habeas retroactivity purposes that does not require a state judge conscientiously to weigh and consider the likelihood that a defendant's federal claim is part of a developing trend.

\section{THE DEFINITION OF "FINAL"}

In Teague, Justice O'Connor defined "new law" as any rule that was not dictated by precedent existing "at the time the defendant's conviction became final."76 Unfortunately, Justice O'Connor did not resolve the issue of when a state conviction beconies "final." At one point in Teague, she quoted Justice Powell's statement in Solem v. Stumes ${ }^{77}$ that the governing law should be the law "in effect at the time of the conviction." 78 Later, she suggested that the test should be whether the "trials and appeals conformed to then-existing constitutional standards."79 Finally, in Penry, she declared that the petitioner's conviction "became final ... . when this Court denied his petition for certiorari on direct review."80

Because Teague was premised on the theory that federal habeas serves to deter constitutional errors by state judges, the appropriate time to "fix" the applicable federal law for purposes of habeas review is when the state judges have rendered their final decision on direct review of the case. Any change in the governing federal law between the last state-court decision affirming a defendant's conviction and the Supreme Court's denial of certiorari, perhaps a year or nore later, is as irrelevant to the "deterrence" theory as a change in the governing federal law occurring after the denial of certiorari. In either case, the propriety of the state court's decision is unaffected.

In addition to the theoretical argument, practical concerns support defining finality in terms of the last state court decision on direct review. A retroactivity rule focusing on the law in existence at the time of the Court's denial of certiorari would create a strong incentive for defendants to file certiorari petitions, hoping that some beneficial new rule might be announced during the pendency of the petition.

\footnotetext{
${ }^{76} 109$ S.Ct. at 1070.

77465 U.S. 638 (1984).

${ }^{78} 109$ S.Ct. at 1073, quoting Stumes, 465 U.S. at 653 (Powell, J., concurring).

79109 S.Ct. at 1075.

80109 S.Ct. at 2944.
} 
This would simply transfer work from the lower federal courts to the Supreme Court.

\section{Teague and Federal Habeas Practice}

\section{A. THE IMPACT ON HABEAS PRACTICE IN THE FEDERAL DISTRICT COURTS AND COURTS OF APPEALS}

In the district courts, the most obvious practical impact will be that prisoners will quickly learn to conform their habeas petitions to the new rnle set out in Teague. Prisoners learned not to allege Fourth Amendment violations after the Court excluded such claims from habeas review in Stone v. Powell, ${ }^{81}$ and to recast Fourth Amendment claims as ineffective assistance of counsel claims after Kimmelman $v$. Morrison. ${ }^{82}$ Similarly, prisoners after Teague will learn to allege that the state courts violated existing federal law, and not to allege claims based on "new law" declared after their convictions became "final," or on requests for adoption of such "new law" by the district court.

The method of reviewing habeas petitions in the district courts will also change as a result of Teague. Whenever a habeas petition is based on an alleged violation of existing federal law, the district court will first have to decide what the law was at the time of the original state proceeding. Under Teague, this inquiry will focus on the existing Supreme Court precedent and any other rules that would have been "dictated" by the precedent. Of course, Penry demonstrates just how difficult such an inquiry can be for a lower court; with respect to Penry's jury instruction claim, the Supreme Court split five-to-four over whether the claim was based on existing law or "new law."

Although the inquiry into the existing federal law will not always be easy, the district courts may find consolation in the fact that there will be very few meritorious second or subsequent petitions. The fact that Teague "freezes" the federal law applicable to a petitioner, coupled with existing habeas doctrines concerning successive petitions and abuse of the writ, ${ }^{83}$ effectively establishes a "one petition"

81428 U.S. 465 (I976).

82477 U.S. 365 (1986). See Manville \& Brezna, Post-Conviction Remedies: A Self-Help Manual, 60-61 (1988) (discussing how state prisoners may recast Fourth Amendment claims as ineffective assistance claims).

${ }^{83}$ See Rule 9(b) of the Rules Governing Section 2254 Cases in the United States District Courts; Sanders v. United States, 373 U.S. I (1963). 
rule. In essence, any claim in a second or subsequent petition based on a new rule that is sufficiently "dictated" by prior precedent to avoid the label, "new law," will be barred because it either was or should have been raised in the first petition. Thus, although Teague may not reduce the total number of federal habeas petitions, it will reduce the burden that review of such petitions imposes on the district courts, because in most instances only a petitioner's first habeas petition will require substantial judicial time and effort.

Of course, a petitioner who can show that his claim fits within one of the exceptions to Teague for certain categories of "new law" will be entitled to relief on a second or subsequent habeas petition, assuming all of the usual procedural requirements are satisfied. But the exceptions have been defined so narrowly that only a handful of "new law" decisions will fit within one of them. The first exception, for substantive rules dealing with the validity of crimes or punishments, will apply to very few decisions outside the context of the death penalty. And, as Justice O'Connor noted in Teague, it is unlikely that many new rules would fit within the second exception, because most rules that might be considered essential to an accurate conviction have already been declared. ${ }^{84}$

The habeas practice in the courts of appeals is likely to change in much the same way that it will change in the district courts. Federal appellate courts will face either claims that the state courts have misapplied existing federal law, or claims that the district courts have misinterpreted some aspect of the Teague rule, such as the scope of "new law" or one of the exceptions to the doctrine. The determination of the existing federal law will often be problematic, but the appellate courts will need to pay little attention to most second or subsequent habeas petitions.

\section{B. THE IMPACT ON HABEAS PRACTICE IN THE SUPREME COURT}

In the Supreme Court, Teague will have a major impact on the habeas caseload. The new retroactivity rule will dramatically reduce the likelihood that a habeas petitioner will obtain a writ of certiorari to challenge the denial of habeas relief by a federal court of appeals. This is because most habeas petitioners who lose in the court of appeals will have only two choices when considering possible certiorari review. The petitioner can file a petition for certiorari alleging that

${ }^{84} 109$ S.Ct. at 1077. 
the state courts misapplied the existing federal law, which is not likely to be viewed by the Supreme Court as an issue worthy of a grant of certiorari. ${ }^{85}$ Alternatively, the petitioner can file a petition for certiorari raising a "new law" issue that might interest the Court, but Teague will prevent the Court from taking such a case to resolve the "new law" issue, unless one of the two exceptions applies. After Teague, therefore, the Court will be likely to review only two kinds of habeas cases: those in which the state warden lost in the court of appeals, and those in which the petitioner lost, but which present a certworthy issue involving the defimition of "new law" or the applicability of one of the exceptions to the Teague rule.

Attorneys who represent many habeas petitioners, such as legal clinics or public defenders, will soon realize that they have very little to gam, and perhaps much to lose for their other habeas clients, by seeking to take a habeas case from the court of appeals to the Supreme Court. This is because, absent an applicable exception, the Court can only rule against a "new law" claim in a habeas case. In the vast majority of cases, the Court cannot adopt "new law" in a habeas petitioner's favor. Once the futility of filing a certiorari petition in a habeas case becoines understood, the number of such filings will likely decrease.

\section{THE SPECIAL CATEGORY OF CAPITAL CASES}

One of the most significant effects of the Teague doctrine will be felt in capital cases. The Teague rnle will shorten federal habeas litigation in capital cases by reducing the time spent in reviewing second or subsequent habeas petitions.

The lengthy delays imcurred as a result of federal habeas litigation in capital cases have been documented and criticized. ${ }^{86}$ The problem is that a capital defendant, unlike all other defendants, has little or no

\footnotetext{
${ }^{85}$ See Rule 17, Rules of the Supreme Court of the United States.

${ }^{86}$ As one recent federal report noted, "[t]he problem of delay [due to habeas litigation] has been particularly acute in capital cases. In such cases, the continuation of litigation prevents the sentence from being carried out." Office of Legal Policy, Report on Federal Habeas Corpus Review of State Judgments 37 (1988) (Truth in Criminal Justice Report No. 7). See also Robbins, Rationalizing Federal Habeas Corpus Review of State Court Criminal Convictions in Capital Cases, Background and Issues Paper, A.B.A. Criminal Justice Section Task Force on Death Penalty Habeas Corpus 8-9 (1989) ("[F]ederal habeas corpus review of [capital] cases appears to most observers to be both chaotic and protracted. . . . Despite the frantic pace of some of these proceedings, death penalty litigation in most eases is quite protraeted. It is rare for a death sentence to be carried out within five or six years of its imposition").
} 
incentive to speed up the pace of habeas review of his conviction and sentence. Quite the contrary-for prisoners on death row, the longer the review process takes, the better.

In recent years, two major reform initiatives have been instituted to deal with this problem. ${ }^{87}$ In September 1989, the Ad Hoc Committee on Federal Habeas Corpus in Capital Cases, also known as the Powell Committee, proposed amendments to the federal habeas statute that would apply only to habeas petitions filed in capital cases. ${ }^{88}$ Under the proposal, if a state provides qualified counsel to handle state post-conviction proceedings in capital cases, then capital defendants in that state would be (1) subjected to a 180-day statute of limitations for filing their federal habeas petitions, with a possible 60-day extension for good cause, (2) limited to one federal habeas petition absent a claim that raises serious doubt about the defendant's guilt, and that was not raised previously because of a valid excuse, such as newly discovered evidence, and (3) prevented from challenging the effectiveness of their state post-conviction attorneys.

The Powell Committee's proposal to provide state post-conviction counsel for capital defendants is laudable, but the remainder of the proposal is nisguided. The proposal reduces the delay in capital cases attributable to habeas litigation by forcing capital defendants to file their first federal habeas petitions sooner than is required of other defendants. The proposal also bars, in capital cases only, all second or subsequent federal habeas petitions that do not raise a serious doubt about factual guilt. These aspects raise serious questions about the actual and perceived fairness of the Powell Committee's proposal. Perhaps not surprisingly, the proposal has drawn fire from con1mentators who, while agreeing with the provision of state postconviction counsel, object strenuously to "singling out" capital cases for accelerated review.

The Teague doctrine will also have an effect on the problem of lengthy habeas litigation in capital cases, although it will do so with-

\footnotetext{
87The American Bar Association has set up a State-Federal Task Force on Death Penalty Habeas Corpus to address the concerns raised by the "chaotic and protracted" federal habeas litigation in capital cases. See Robbins, note 86 supra, at 8-9, 13. In addition, Chief Justice William H. Rehnquist in January, 1988, requested the Conference of Chief Justices to study ways to deal with the problems of federal habeas litigation in eapital cases. See $i d$. at 12 . This request led to the creation of the Ad Hoc Committee on Federal Habeas Corpus in Capital Cases, an organ of the Judicial Conference of the United States chaired by retired Justice Lewis F. Powell, Jr. The Committee has come to be known as the Powell Committee.

${ }^{88}$ See 45 Crim. L. Rep. (BNA) 3239-3245 (September 27, 1989).
} 
out "singling out" capital cases for special treatment. What must be recognized is that the delay caused by habeas litigation in capital cases is often a direct product of habeas retroactivity. A common scenario looks like this: The state sets an execution date. A few days before the scheduled execution, the defendant files a federal habeas petition in the district court, raising one or more colorable constitutional claims in an effort to get a stay of execution. Unable to resolve the merits of the habeas petition before the scheduled execution, the district court or court of appeals grants a stay. ${ }^{89}$ The standard review process, including a petition for certiorari to the Supreme Court, takes a year or more. Meanwhile, a year's worth of new constitutional criminal procedure decisions have been issued by the federal courts. Certiorari is denied, and the state sets a new execution date. Now the cycle begins again, with the defendant raising all of the "new law" claims based on the intervening year's decisions.

This potentially endless cycle of habeas review will be cut short, in most capital cases, by the Teague doctrine. Because the definition of "new law" in Teague is so broad, the federal courts will find it easy to dismiss second or subsequent habeas petitions on the ground that the claims contained therein are based on "new law." Alternatively, petitions raising clainis not based on "new law" will be easily dismissed as a successive petition or an abuse of the writ. Either way, the courts will be able to dismiss such petitions quickly enough to avoid the need for a stay of execution. Without a stay of execution, the cycle ends.

The ouly "new law" claims that will entitle a capital defendant to relief on a second or subsequent habeas petition will be those that fit within one of the exceptions to the Teague doctrine. Thus, the ouly second or subsequent petitions that will require a stay of execution will be those raising a substantial claim that likely fits within one of the exceptions. Of course, one of the exceptions, after Penry, includes all substantive Eighth Amendment challenges to the validity of the death penalty for particular classes of defendants or crimes. And the exception for clainis based on procedures without which there is a substantial likelihood that an innocent defendant would be

\footnotetext{
${ }^{89}$ In Barefoot v. Estelle, 463 U.S. 880 (1983), the Supreme Court authorized the lower federal courts to adopt procedures for expedited review of capital habeas cases on motions for stays of execution. However, a stay will be granted where the defendant makes a "substantial showing of the denial of [a] federal right" and where a stay is required to prevent the case from becoming moot. Id. at 893 .
} 
convicted will also be triggered by some "new law" decisions in the capital context. But these exceptions will likely apply to only one or two decisions each Term, and not all capital defendants will be entitled to relief under such decisions. In most capital cases, the Teague doctrine will eliminate the need for federal courts to spend much time reviewing second or subsequent petitions, and will thereby avoid the cycle of habeas review.

\section{Teague and the Development of Federal Constitutional Rules of Criminal Procedure}

Perhaps the most far-reaching consequence of Teague will be its institutional effect on the development of federal constitutional rules of criminal procedure. The extent of this effect cannot be estimated with precision at the present time. Nevertheless, it is quite possible that Teague, because of its relocation of responsibility among the various institutions that participate in the development of constitutional criminal procedure, will tip the sensitive criminal procedure balance toward the societal interest in preventing and punishing crime, and away from the rights of the individual criminal defendant. ${ }^{90}$

The constitutional criminal procedure "revolution" of the 1960s and 1970s took place almost exclusively in the federal courts. The Supreme Court, of course, during and even after Chief Justice Warren's tenure, led the way. But the lower federal courts played an important role as well, advancing the "revolution" directly by interpreting and applying the Court's new precedents, and indirectly by framing many criminal procedure issues for the Court's subsequent consideration. ${ }^{91}$

Today, the "revolution" has ended, and federal constitutional rules of criminal procedure are evolving at a much more leisurely pace. But it is still true that the federal courts, and particularly the lower courts, play a central role in the development of constitutional criminal procedure.

Meanwhile, the inclinations of state courts to expand, or to protect vigilantly, the rights of defendants vary widely. In recent years, when many federal courts have become less sympathetic to defendants' rights, some state courts have interpreted their state constitutions to

\footnotetext{
${ }^{90}$ See Packer, The Limits of the Criminal Sanction, 149-73 (1968).

91See Cover \& Aleinikoff, Dialectical Federalism: Habeas Corpus and the Court, 86 Yale L.J. 1035 (1977).
} 
provide greater protection for defendants than the comparable federal constitutional provisions. ${ }^{92}$ Other state courts, however, continue to construe both their state constitutions and the federal constitution narrowly, recognizing defendants' claims only when compelled to do so by controlling precedent. ${ }^{93}$ The views of these courts may reflect hostility toward defendants or simply the inevitable effect of institutional differences between the federal and state courts. ${ }^{94}$

After Teague and Penry, the lower federal courts will find themselves significantly less capable of participating meaningfully in the development of federal constitutional rules of criminal procedure. Outside the context of the Fourth Amendment, most of the opportumities for the lower federal courts to declare "new rules" of constitutional criminal procedure, or to expound on the meaning or application of such "new rules," arise in federal habeas cases. This is because there are many more state criminal prosecutions than federal ones, and because state procedures vary more than do federal procedures, thus raising more interesting and difficult criminal procedure issues.

The institutional effect of Teague will be to deprive the lower federal courts of most of their opportunities to make "new law" in federal habeas cases, or at least to make "new law" in a criminal defendant's favor. And, of course, the lower federal courts do not have the power to review state criminal cases on direct appeal. Thus, Teague will shift the primary responsibility for the development of federal rules of constitutional criminal procedure, in the sense of interpreting and applying new Supreme Court precedents and framing issues for the Court's consideration, from the lower federal courts

\footnotetext{
${ }^{22}$ See Latzer, Limits of the New Federalism: State Court Responses, 14 Search \& Seizure L. Rep. 89 (1987) (listing state courts that have rejected narrow Supreme Court interpretations of the Fourth Amendment); see generally Brennan, State Constitutions and the Protection of Individual Rights, 90 Harv. L. Rev. 489 (1977).

93 See Bradley, Are State Courts Enforcing the Fourth Amendment? A Preliminary Study, $77 \mathrm{Gco}$. L.J. 251 (1988) (suggesting that state courts in Georgia, and perhaps in Arizona and South Carolina, have stopped enforcing the Fourth Amendment since Stone v. Powell, 428 U.S. 465 (1976), removed such claims from federal habeas review).

${ }^{94}$ See Neuborne, The Myth of Parity, 90 Harv. L. Rev. 1105, 1115-28 (1977); see also Chemerinsky, Parity Reconsidered: Defining a Role for the Federal Judiciary, 36 U.C.L.A. L. Rev. 233 (1988); Redish, Judicial Parity, Litigant Choice, and Democratic Theory: A Comment on Federal Jurisdiction and Constitutional Rights, 36 U.C.L.A. L. Rev. 329 (1988); Chemerinsky, Federal Courts, State Courts, and the Constitution: A Rejoinder to Professor Redish, 36 Ụ.C.L.A. L. Rev. 369 (1988).
} 
to the state courts. Only the Court itself will be able to "converse" with the state courts on issues of constitutional criminal procedure. ${ }^{95}$

The increase in recent years in prosecutions for federal crimes, such as drug and white-collar offenses, will provide the lower federal courts with some opportunities to declare "new law." This will be true especially in areas of constitutional criminal procedure that are likely to arise in federal criminal cases, such as constitutional rules relating to grand jury practice. And the exceptions to the Teague rule will allow some federal habeas cases involving "new law" issues to get into the lower federal courts. Nevertheless, by removing from the scope of federal habeas most claims of state prisoners that are based on "new law," Teague will greatly reduce the opportunities for the lower federal courts to advance the development of constitutional criminal procedure.

The shifting of primary responsibility for the development of constitutional criminal procedure from the lower federal courts to the state courts will likely produce two long-term effects. First, it will produce more conflicts in the interpretation and application of criminal procedure rules, because the lower federal courts will no longer be able to use federal habeas to discourage the states in a single federal circuit from adopting different points of view. Second, and more importantly, it will alter, at least in some states, the degree of procedural protection afforded defendants. In states where the state courts are more sympathetic to defendants than the federal courts, there will be no such effect, because those state courts can already provide added protection under their state constitutions. But where the state courts are less sympathetic than their federal counterparts, defendants will suffer, because the unsympathetic state courts will control the interpretation and application of both the state and the federal constitutions. It is in this sense that Teague may tip the criminal procedure balance toward crime control and away from the rights of the individual defendant.

\section{Conclusion}

In Teague v. Lane and Penry v. Lynaugh, the Supreme Court did what commentators have been suggesting for a long time-a majority of the Court agreed upon a single, coherent theory that explains

\footnotetext{
${ }^{95}$ See Cover \& Aleinikoff, note 91 supra, at 1052-54.
} 
the purpose of federal habeas corpus review of state criminal convictions. As I have explained in this article, the full impact of the Court's new vision of federal habeas may surprise a great many people. Perhaps the Court, or Congress, will ultimately decide to modify the Teague habeas retroactivity rule and ameliorate some of the effects I have identified. In the ineantime, however, the Teague rule will likely force courts, litigants, and commentators to rethink their entire approach to issues of habeas law and practice. 
